Archives of Agriculture and Environmental Science

\title{
Participatory assessment of lentil (Lens culinaris Medik.) production practices in marginal dry lands of Wag-lasta, Ethiopia
}

\section{Ademe Mihiretu* (D), Melaku Asresu and Adane Wubet}

Socioeconomic and Agricultural Extension Research Directorate Sekota Dry-land Agricultural Research Center, Po. Box 62, Sekota, ETHIOPIA

"Corresponding author's E-mail: ademe_78@yahoo.com.sg

\section{ARTICLE HISTORY}

Received: 02 July 2019

Revised received: 31 July 2019

Accepted: 23 August 2019

\section{Keywords}

Lentil (Lens culinaris Medik.) variety

Marginal rate of return

Preference parameter

Weight ranking matrix

\begin{abstract}
Lentil (Lens culinaris Medik.) is an important legume for human nutrition, animal feeding and soil fertility enhancement in Wag-lasta areas of Ethiopia. Despite its importance, concerned actors in the extension system have inconsistencies on the efficient production practices. The participatory assessment of different lentil production practices was thus carried out involving twenty-three farmers in the marginal dry lands of Wag-lasta area. The experiment was designed to evaluate and demonstrate the performance of different lentil production practices to farmers and extension personnel to settle the paradox in the extension system. It was directed through comparing the improved variety with its full production package (IPP) against the local variety with full package (LPP) and local variety under farmers' practice (LFP). Agronomic, economic and preference data were collected and analysed in descriptive statistic, ANOVA, partial budgeting and weighted ranking matrix. The combined result indicated that LPP, LFP and IPP provided mean grain yields of 806,584 and $486 \mathrm{~kg} \mathrm{ha}^{-1}$, respectively. Accordingly, LPP has 27.5 and $39.7 \%$ yield advantage over LFP and IPP, respectively. The marginal rate of return of LPP is 334.9 and $411 \%$ in Sekota and Lalibela districts in that order. The overall weighted ranking matrix also shows that LFP and LPP were farmers' first and second choices in Sekota but vice versa in Lalibela district. Farmers and experts in the extension system thus perceived and approved the prominence of local cultivar under full package practice. Therefore, large-scale dissemination of the local cultivar with its full package components is safely recommended.
\end{abstract}

(C)2019 Agriculture and Environmental Science Academy of this article: Mihiretu, A., Asresu, M. and Wubet, A. (2019). Participatory assessment of lentil (Lens culinaris Medik.) production practices in marginal dry lands of Wag-lasta, Ethiopia. Archives of Agriculture and Environmental Science, 4(3): 288-294, https://dx.doi.org/10.26832/24566632.2019.040305

\section{INTRODUCTION}

Lentil (Lens culinaris Medik.) is one of the most ancient annual food crops that have been grown as an important food source for over 8,000 years. It has been established in a wide range of agro-ecologies but production is limited to tropical areas (Dhuppar et al., 2012). The spread of lentil from the centre of origin has been accompanied by the selection of traits important for adaptation to environments that can be climate, soil and their impact on season length, abiotic and biotic stresses (Materne and Siddique, 2009; Bacchi et al., 2010). It is an important crop in food, feed and farming systems of West Asia and North and East Africa. Lentil plays a significant role in human and animal nutrition and in maintenance and improvement of soil fertility (Sarker and Kumar, 2011). Its cultivation enriches soil nutrient status by adding nitrogen, carbon and organic matter which promotes sustainable cereal based systems of crop production (Piergiovanni, 2000). The protein enrichment of lentil makes the preferred pulse crop to rural poor households worldwide thus productivity enhancement activities are very (Frederick et al., 2006).

Ethiopia is considered as a center of diversity for lentil and currently lentil is an important pulse crop. It is also one of the major lentil-producing countries in Africa and is listed in the top 
ten countries in the world (FAO, 2016). Lentil is amongst the principal cool season food legumes in Ethiopia (Joseph et al., 2014). It is less selective legumes in terms of climate and soil features, performs best on deep, sandy and loam soils (IBC, 2007). Different types of lentils are now grown in large areas of warm temperate, subtropical and high altitude of the tropics as a cool season crop (Getahun, 2016). Lentil is considered as drought-resistant crop that can tolerate low annual rainfall distribution ranging from 280-300 mm (Erksine, 1983). Despite this fact, lentil production is not mechanized rather produced by smallholder farmers under fragmented plots mainly for household consumption (Jarso et al., 2009; Abraham, 2015). Average lentil productivity is about 1230, 1150 and $1260 \mathrm{~kg} \mathrm{ha}^{-1}$ for Ethiopia, Africa and the World, respectively.

However, improved varieties can yield 1.4-5.0 $\mathrm{t} \mathrm{ha}^{-1}$ under research sites and 0.9-3 ton $\mathrm{ha}^{-1}$ on farmers' field using full agronomic packages (MOARD, 2015). The vast productivity difference between farmer's field and research station is due to inconsistency in crop husbandry practices such as soil, fertilizer and water management (FAO, 2016).

Currently, crop productivity has changed significantly due to the release of improved varieties as well as modernisation of husbandry practices in Ethiopia, however still lentil is low in productivity compared to other legumes (Bejiga and Anbessa, 1998). Lentil research has released nearly 10 varieties, among these three were released for the low land dry areas while five were for the central, northern and south eastern highlands of Ethiopia (Yasin, 2015). However, it was difficult for the researchers to deliver these varieties to farmers since they keep using local seeds. In the central high lands of Ethiopia, only $9 \%$ of lentil growers adopted improved varieties due to associated disease and insect incidence to these varieties (Dugassa et al., 2015). Local cultivars have limited yield potential and are also vulnerable to an array of stresses. Lentil has been under-utilised in relative to other pulses. Despite breeders have developed nearly ten improved varieties in Ethiopia; the uptake of these varieties is limited due to little participatory research outside breeding (Cokkizgin and Munqes, 2013).

In wag-lasta area, lentil production covers nearly 297,427 ha of land with average yield of $1109 \mathrm{~kg} \mathrm{ha}^{-1}$, which is lower than other zones in the Amhara region (CSA, 2016). Though lentil has the ability to grow in marginal environments, its productivity is very low in Wag-lasta due to yield-limiting factors like the inherent low yielding genetic potential of widely growing local cultivars and traditional agronomic practices (Yirga and Zinabu, 2018). Despite the country's potential and sustained development efforts, the economic contribution of lentil is threatened by low productivity and inconsistent product supply to the international and local markets. Inadequate supply and limited popularization of improved varieties is also the limiting factor for farmers' adoption (Resenberg, 2005). The bottlenecks for lentil improvement are issues of availability, quality and sustainably coming from seed technology on top of deficient production packages. There was a need to supply varieties adaptable, productive and suitable to moisture stressed areas through identifying best performing improved varieties and applicable production packages. Hence, improved lentil variety and production package was recommended for Wag-lasta moisture deficit areas in the north-eastern Amhara region (Yirga and Zinabu, 2018).

However, stakeholders in the extension system (viz., researchers, extension workers and farmers) have inconsistencies on the recommended lentil production packages and practices in Wag-lasta area. Thus, agricultural researchers advised the use of improved varieties with its full package as inevitable solution for lentil production enhancement. On the other hand, farmers are sticking to their inherent local lentil cultivars and traditional agronomic practices trusting that minimum yield difference among advocated and prevailing production practices (Kumar et al., 2013; Yirga and Zinabu, 2018). While the extension workers argue that, fertiliser application is an extravagant for lentil production though they have no doubt on the use of improved varieties. Therefore, the current study is generally intended to crack the paradox in the extension system on lentil production practices in marginal dry lands of Wag-lasta, Ethiopia. The evaluation was thus conducted under farmers' situation to assess the varietal as well as package application gaps in lentil production. The specific objectives were designed basically to identify and demonstrate the efficient and acceptable lentil production practice to farmers and extension personnel through participatory approach.

\section{MATERIALS AND METHODS}

\section{Description of the study area}

The experiment was conducted in two districts of Wag-lasta area in the north-eastern Amhara region. The districts (Sekota and Lalibela) were having relatively similar agro ecology suitable to lentil production in the marginal drylands of Wag-lasta area. Sekota district is found at $12^{\circ} 68^{\prime} 35^{\prime \prime} \mathrm{N}$ and $39.01^{\prime} 41^{\prime \prime} \mathrm{E}$ latitude and longitude with an altitude of $1976 \mathrm{~m}$ above sea level. It has an average annual rainfall of 500 to $650 \mathrm{~mm}$ with minimum and maximum temperatures of 26.6 and $31.6^{\circ} \mathrm{C}$ respectively. On the other hand, Lalibela district is located at $12^{\circ} 55^{\prime} 559^{\prime \prime} \mathrm{N}$ latitude and $38^{\circ} 42^{\prime} 293^{\prime \prime} E$ longitude at an altitude of $2400 \mathrm{~m}$ above sea level with a mean annual temperature and rainfall of $26.2^{\circ} \mathrm{C}$ and $895.2 \mathrm{~mm}$, respectively (WOA, 2015).

\section{Treatments, experimental design and farmers participation} The participatory on-farm evaluation and demonstration of different lentil production practices were conducted for two consecutive cropping seasons (2017-18 and 2018-19). Two districts in Wag-lasta area, representing the lentil production recommendation domain were purposively selected. On the bases of accessibility, nine willing farmers per district on top of five farmers' training centres (FTCs) were identified to host the trial. Except the trial plot and its management cost, other expenses of the experiment were covered by the research centre. The experimental treatments were arranged in un-replicated simple block considering farmers as replications. They were laid on three side by side plots having an area of $100 \mathrm{~m}^{2}$ each in the 
following order: improved variety with full package practice (IPP), local cultivar with full package practice (LPP) and local cultivar with farmers' traditional practice (LFP). The improved variety was compared with the local cultivar under full package practice to show changes achieved by improved variety, keeping package components constant. While the local cultivar was managed in full package practice as well as farmers' prevailing practice in order to show changes attained due to full package application, keeping the variety constant. The full package practice in this study comprises components (viz., suggested seed and fertilizer rates, inter and intra row spacing, land preparation and weeding rate at optimum level).

Therefore, full package practices were planted in row at 120 and $100 \mathrm{~kg} \mathrm{ha}^{-1}$ seed and fertilizer rates, respectively. Di ammonium phosphate (DAP) fertilizer was applied by hand drilling, keeping intra and inters row spacing of $0.05 \mathrm{~m}$ and $0.2 \mathrm{~m}$, respectively. Land preparation and weeding were done as per the recommendation (3x-plowing and 2x-weeding). The farmers' traditional practice was sown in broadcast without fertilizer at $150 \mathrm{~kg} \mathrm{ha}^{-1}$ seed rate as well as $2 x$-plowing and zero weeding. Earlier to the experiment, strong linkage among the multidisciplinary team (extension personnel, farmers and researchers) was created to share duties throughout the experiment course. Training and indepth discussion with these actors were held to convey awareness about the experimental objectives. The training includes on job practical exercise on package application (viz., spacing, seed rating and drilling, fertilizing as well as disease and insect incidence diagnosis) were provided to farmers to ensure their participation and feel responsible in the trial. The training, technical backstopping and data collection were managed by researchers. Farmers and experts were involved in plot and layout preparation, sowing, fertilizing, field management and at performance evaluation stages.

\section{Data types and collection methods}

Quantitative and qualitative data types were collected employing checklists and focus group discussions (FGDs). Secondary data was also collected from different published and unpublished sources to triangulate and support results from the trial. The quantitative data (days to maturity, grain and biomass yields) were collected at plot levels to calculate the technological gap, extension gap and the technological index. Economic data (costs and benefits) were collected to compare the economic efficiency of treatments. Total variable cost was taken from input (seed, fertilizer and labour) prices, keeping land constant. Yield was adjusted by $10 \%$ and the selling prices of grain and biomass yields at the farm gate were taken to calculate the total income. The average labour cost for package practices (row planting and weeding) was expressed in person day, where one person day was assumed to be 8 hours of work. The farmers' preference data was collected organizing FGDs in each district before harvest (i.e. at physiological maturity). The evaluation was apprehended as a group through assigning literate farmers in each group to lead the discussion since most of the farmers were unable to read and write. The participant farmers hence brainstormed to identify their evaluation criteria to be considered in the selection of best lentil production practice. Crop yield, biomass yield, earliness, seed boldness, tolerance to pest and tolerance to lodging were agreed preference parameters of farmers across locations.

\section{Data analysis}

\section{Biological data analysis}

The quantitative data (days to maturity, grain and biomass yields) were analysed in descriptive statistics like mean, frequency and percentages. The technological gap, varietal gap and technological index were calculated with the formulas provided by Yadav et al. (2004).

Technology gap $=$ improved yield - farmers' yield............ (1)

Variety gap = improved yield - yield from local variety under full package.

Technology index $(\%)=($ technology gap $/$ potential yield $) \times$ 100 .

Data from treatments (IPP, LPP, LFP) were subjected twice to analysis of variance (ANOVA) followed by Tukey's test (HSD) (SPSS, 2007). The first of which was depending on agronomic records as explanatory variables and the second was depending on the indicative scores as explanatory variables. The coefficient of determination $\left(R^{2}\right)$ and the Tukey's test (HSD) has been applied to significant variables in both analyses. The data of the indicative scores of sites for the three agronomic records were standardized and the sample variance $\left(\mathrm{S}^{2}\right)$ has been calculated from the following formula:

$$
\mathrm{s}^{2}=\Sigma(\mathrm{xi}-\mathrm{x})^{2} / \mathrm{n}-1
$$

where $S^{2}$ is sample variance, $\Sigma$ is sum, $x_{i}$ is the term in data set (indicative scores of sampling sites), $x$ is sample mean, and $n$ is sample size (Alaa and Mahgoub, 2019). The results of ANOVA $\left(R^{2}, F, P\right)$ and the sample variance $\left(S^{2}\right)$ have been taken to express for the impact of the agronomic records and their order of importance, on the different treatments of the trial area.

\section{Partial budget analysis}

It is calculated taking the additional input costs involved and the returns obtained after harvesting. The net benefit was the resultant of deduction between gross return and total variable cost. Marginal cost was calculated by deducting the total variable cost of improved practices with respect the cost of previous practice while the marginal net benefit was calculated by deducting the net benefit of improved practices with respect to the net benefit of forgoing practices. The marginal rate of return (MRR) of one treatment to the other was calculated as:

$$
M R R=\frac{\Delta N B}{\Delta T V C} \times 100
$$

Where: DNB = change in net benefits and DTVC = change in total variable input costs. The minimum return which farmers 
expect to earn from a technology called acceptable minimum rate of return (AMRR) is set to between 50 and $100 \%$ because the technology package is new to the farmers so that required for them to introduce some new skills; hence 50\% AMRR was taken as a reasonable estimate. All costs and benefits were valued in monetary terms (Ethiopian birr) calculated at the farm gate prices (CIMMYT, 1998).

\section{Preference analysis}

Farmers and their spouses were alienated into sex disaggregated groups. Each group was assigned to visit two arbitrary trial sites then each farmer to come across private criterion. After a number of round way trips on assigned replications farmers as group were coupled with a hot discussion to come up with common ranking preferences (Eba and Nano, 2018). Finally, the groups present their criterion to participants thus each group's entire preference summed to identify and score the most common once. To summarize all rankings, tally method was used in which the first, second, third, fourth, fifth and sixth ranking had weighted value of six, five, four, three, two and one points, respectively then weighted ranking matrix table was constructed. Farmers in each group were asked to compare treatments each other and then to give values based on the identified parameters thus counting the values provided to put scores. The scores given by farmers to each practice were multiplied by the respective weight. Products were aggregated for each treatment for final selection (the higher sum was ranked first) (Russell, 1997).
Spearman's rank correlation wasused to see the degree of coincidence between farmers' preference rank and the actual value of measured attributes (Ferdous et al., 2016).

The correlation coefficient is defined as:

$$
\mathrm{r}_{s}=1-\frac{6 \sum d^{2}}{n\left(n^{2}-1\right)}
$$

Where, $d=$ difference in the ranks assigned to the same phenomenon and $\mathrm{n}=$ number of phenomena ranked.

\section{RESULTS AND DISCUSSION}

Performances of different lentil production practices The results revealed that, LFP provided a mean grain yield of 584 $\mathrm{kg} \mathrm{ha}^{-1}$ while IPP and LPP had mean grain yields of 486 and $806 \mathrm{~kg}$ $\mathrm{ha}^{-1}$ respectively (Table 1 ). Therefore, IPP had a yield penalty of 65.4 and $20.2 \%$ from LPP and LFP, respectively. This was mainly attributed to the late maturity status of the improved package practice. This result is in disagreement with the finding of Yirga and Zinabu (2018) who obtained higher yield during adaptation experiment. Nonetheless, IPP and LPP out-yielded LFP in biomass output. The gap between LPP and LFP due to use of the package practice was $29.7 \%$, revealed that lentil production could overwhelmed by adopting efficient package practice. The negative technological index provided evidence that necessitate wider scope of improvements in lentil production; hence this finding is in agreement with Yadav et al. (2004).

Table 1. Mean grain yield, stalk yield and days to maturity of treatments across districts.

\begin{tabular}{lcccccccccc}
\hline \multirow{2}{*}{ Districts } & \multirow{2}{*}{ Sites } & \multicolumn{3}{c}{ Mean grain yield $\left(\mathrm{kg} \mathrm{ha}^{-1}\right)$} & \multicolumn{3}{c}{ Mean biomass yield $\left(\mathrm{kg} \mathrm{ha}^{-1}\right)$} & \multicolumn{3}{c}{ Average days to maturity } \\
\cline { 3 - 9 } & & IPP & LPP & LFP & IPP & LPP & LFP & IPP & LPP & LFP \\
\hline Sekota & 8 & 549 & 865 & 667 & 1155 & 1354 & 1154 & 109 & 96 & 88 \\
Lalibela & 8 & 426 & 747 & 502 & 1172 & 1244 & 949 & 108 & 101 & 90 \\
Combined & 16 & 486 & 806 & 584 & 1164 & 1299 & 1052 & 109 & 98 & 89 \\
\hline
\end{tabular}

Table 2. Varietal gap, technological gap and index in the lentil production practice evaluation.

\begin{tabular}{lccccccc}
\hline \multirow{2}{*}{ Districts } & \multicolumn{2}{c}{ Range yield index $\left(\mathrm{kg} \mathrm{ha}^{-1}\right)$} & \multirow{2}{*}{ Variety gap $\left(\mathrm{kg} \mathrm{ha}^{-1}\right)$} & \multirow{2}{*}{ Technology gap (kg ha $\left.{ }^{-1}\right)$} & Technology index (\%) \\
\cline { 2 - 5 } & IPP & LPP & LFP & & -118 & -11 \\
\hline Sekota & $400-710$ & $680-1160$ & $490-810$ & -316 & -76 & -5 \\
Lalibela & $150-610$ & $590-950$ & $250-640$ & -321 & -98 & -7.8 \\
Mean & & & & -320 & & \\
\hline
\end{tabular}

Source: Own experiment (2018).

Table 3. ANOVA test on variations in grain yield, biomass yield and maturity days across districts.

\begin{tabular}{|c|c|c|c|c|c|c|c|c|c|c|c|}
\hline \multirow[b]{2}{*}{ Parameters } & \multirow{2}{*}{$\begin{array}{l}\text { Source of } \\
\text { variation }\end{array}$} & \multicolumn{5}{|c|}{ Sekota } & \multicolumn{5}{|c|}{ Lalibela } \\
\hline & & $\begin{array}{l}\text { Sum of } \\
\text { Squares }\end{array}$ & df & $\begin{array}{l}\text { Mean } \\
\text { Square }\end{array}$ & $\mathbf{F}$ & Sig. & $\begin{array}{l}\text { Sum of } \\
\text { Squares }\end{array}$ & df & $\begin{array}{l}\text { Mean } \\
\text { Square }\end{array}$ & $\mathbf{F}$ & Sig. \\
\hline \multirow{3}{*}{$\begin{array}{l}\text { Grain yield } \\
\left(\mathrm{kg} \mathrm{ha}^{-1}\right)\end{array}$} & Treatments & 4146.6 & 2 & 2073.4 & 12.67 & $.000^{* * *}$ & 4481.3 & 2 & 2240.7 & 13.3 & $.000^{* * *}$ \\
\hline & Errors & 3435.8 & 21 & 163.6 & & & 3552.6 & 21 & 169.2 & & \\
\hline & Total & 7582.5 & 23 & & & & 8034.0 & 23 & & & \\
\hline \multirow{3}{*}{$\begin{array}{l}\text { Biomass } \\
\text { yield } \\
\left(\mathrm{kg} \mathrm{ha}^{-1}\right)\end{array}$} & Treatments & 2120.1 & 2 & 1060.4 & 4.56 & $.023^{* *}$ & 3781.0 & 2 & 1890.5 & 3.5 & $.048^{* * *}$ \\
\hline & Errors & 4885.8 & 21 & 232.7 & & & 11301.6 & 21 & 538.2 & & \\
\hline & Total & 7005.9 & 23 & & & & 15082.6 & 23 & & & \\
\hline \multirow{3}{*}{$\begin{array}{l}\text { Days of } \\
\text { maturity }\end{array}$} & Treatments & 165.9 & 2 & 82.9 & 169.5 & $.000^{* * *}$ & 13.9 & 2 & 6.93 & 180.7 & $.000^{* * *}$ \\
\hline & Errors & 10.3 & 21 & 4.9 & 12.67 & & 0.81 & 21 & .38 & & \\
\hline & Total & 17.6 & 23 & & & & 14.7 & 23 & & & \\
\hline
\end{tabular}

Note that ${ }^{* *},{ }^{* * *}$ imply significance levels at 5 and $1 \%$, respectively. 
The ANOVA table is constructed to illustrate the effects of treatments and other factors like experimental errors on the parameter values under consideration. The post hoc (TukeyHSD) analysis also carried out to compare means of every pair of treatments (i.e., identifying which treatment has significantly larger mean as compared to the other treatment). Therefore, as depicted in Table 3 below, the ANOVA test revealed that there is statistically significant difference in grain yield and stalk yield and days to maturity between treatments in both districts $(P<5 \%)$. The Tukey-HSD test also indicated that among treatments, LPP was best performing technology in grain and biomass yields while the LFP was best in days to maturity across districts at less than $5 \%$ significant level (Table 4).

\section{Partial budget analysis}

The total variable cost of LFP was lower than that of IPP and LPP, but the higher net benefit is obtained from LPP in both districts (Table 5). Therefore, LPP had a net benefit of ETB 16,723.7 and 12,169.3 in Sekota and Lalibela districts, respectively. The lowest return is recorded from IPP with the net benefit of ETB 8759.4 and 4907.9 in Sekota and Lalibela districts, respectively. In general, treatments LPP, LFP and IPP were preferred as first, second and third in their net benefit across districts. The highest marginal rate of returns of 334.9 and $411 \%$ are noted for LPP in Sekota and Lalibela districts, respectively. This implies that for every ETB 1.00 investment in the production package practice (shifting from LFP to LPP), farmers can get an additional ETB 4.11 and 3.35 in Sekota and Lalibela districts, respectively after covering the cost. However, the marginal return of an investment in IPP was not promising compared to that of LPP and LFP in both districts. This provides extra information that the improved variety was not suitable for these areas despite the application of package components was rewarding.

\section{Farmers' preference comparison}

Farmers set out context specific criteria to select and rank treatments. Grain yield, biomass yield, earliness, seed boldness, tolerance to pest and lodging were the identified criterion having dissimilar weight across districts (Table 6). Based on the overall preference criteria, treatments LFP and LPP were the farmers' first and second choices in Sekota but vice versa in Lalibela district. The weighted ranking matrix result showed that IPP was not selected by farmers in both districts as it fails to score better in grain yield, earliness and tolerance to pest. This result is thus against the finding by Yirga and Zinabu (2018), which states that the improved variety under full package was farmers' primary choice. Spearman's correlation on the degree of coincidence between farmers' preference rank and the actual values rank for grain yield, biomass yield and earliness attributes were examined (Table 7). Farmers' preference rank was hence conceded with the measured actual rank of grain yield by $50 \%$ in both districts. Likewise, farmers' preference on earliness attribute was coincided with the actual values rank at 100 and 75\% in Sekota and Lalibela districts, respectively.

Table 4. Tukey-HSD test to identify best performing technology in grain yield, biomass yield and days to maturity across districts.

\begin{tabular}{|c|c|c|c|c|c|c|c|}
\hline \multirow[b]{2}{*}{ Parameters } & \multirow[b]{2}{*}{$\begin{array}{c}\text { Pair of } \\
\text { varieties }\end{array}$} & \multicolumn{3}{|l|}{ Sekota } & \multicolumn{2}{|r|}{ Lalibela } & \multirow[b]{2}{*}{$\begin{array}{l}\text { Tukey-HSD } \\
\text { Sig. }\end{array}$} \\
\hline & & $\begin{array}{c}\text { Mean } \\
\text { Difference }\end{array}$ & $\begin{array}{l}\text { Std. } \\
\text { Error }\end{array}$ & $\begin{array}{l}\text { Tukey-HSD } \\
\text { Sig. }\end{array}$ & $\begin{array}{c}\text { Mean } \\
\text { Difference }\end{array}$ & $\begin{array}{l}\text { Std. } \\
\text { Error }\end{array}$ & \\
\hline \multirow{3}{*}{$\begin{array}{l}\text { Grain yield } \\
\left(\mathrm{kg} \mathrm{ha}^{-1}\right)\end{array}$} & IPP - LPP & $-318.8^{* * *}$ & 63.96 & .000 & $-320.0^{* * *}$ & 65.03 & .000 \\
\hline & IPP - LFP & -120.0 & 63.96 & .170 & -75.0 & 65.03 & .493 \\
\hline & LPP - LFP & $198.8^{* * *}$ & 63.96 & .014 & $245.0^{* * *}$ & 65.03 & .003 \\
\hline \multirow{3}{*}{ Biomass yield $\left(\mathrm{kg} \mathrm{ha}^{-1}\right)$} & IPP - LPP & $-198.8^{* *}$ & 76.27 & .042 & -72.5 & 115.99 & .808 \\
\hline & IPP - LFP & 1.25 & 76.27 & 1.000 & 222.5 & 115.99 & .158 \\
\hline & LPP - LFP & $200.0^{* *}$ & 76.27 & .040 & $295.0^{* *}$ & 115.99 & .048 \\
\hline \multirow{3}{*}{ Days of maturity } & IPP - LPP & $12.75^{* * *}$ & 1.12 & .000 & $7.5^{* * *}$ & .98 & .000 \\
\hline & IPP - LFP & $20.13^{* * *}$ & 1.12 & .000 & $18.5^{* * *}$ & .98 & .000 \\
\hline & LPP - LFP & $7.38^{* * *}$ & 1.12 & .000 & $11.0^{* * *}$ & .98 & .000 \\
\hline
\end{tabular}

Note that $* *, * * *$ imply significance levels at 5 and $1 \%$, respectively.

Table 5. Partial budget analysis of different lentil technologies across districts.

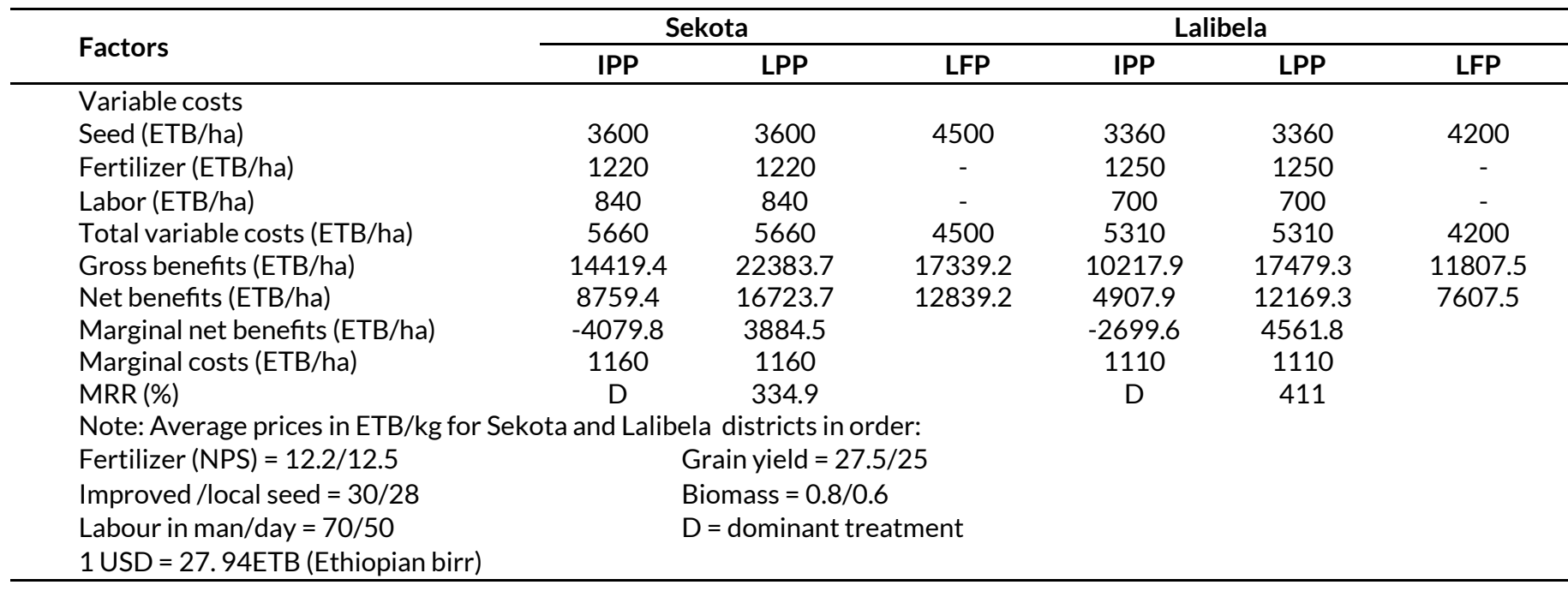


Table 6. Summary of farmers' evaluation criteria and preference ranking across districts.

\begin{tabular}{|c|c|c|c|c|c|c|c|}
\hline \multirow{2}{*}{ Weighted parameters } & & \multicolumn{3}{|c|}{ Sekota } & \multicolumn{3}{|c|}{ Lalibela } \\
\hline & & IPP & LPP & LFP & IPP & LPP & LFP \\
\hline \multirow{4}{*}{ Seed boldness } & Score & 0.00 & 0.00 & 0.00 & 3.00 & 3.00 & 2.00 \\
\hline & Weight & 0.00 & 0.00 & 0.00 & 1.00 & 1.00 & 1.00 \\
\hline & Score ${ }^{*}$ weight & 0.00 & 0.00 & 0.00 & 3.00 & 3.00 & 2.00 \\
\hline & Score & 1.00 & 2.00 & 3.00 & 2.00 & 2.00 & 3.00 \\
\hline \multirow{3}{*}{ Early maturity } & Weight & 4.00 & 4.00 & 4.00 & 4.00 & 4.00 & 4.00 \\
\hline & Score ${ }^{*}$ weight & 4.00 & 8.00 & 12.0 & 8.00 & 8.00 & 12.0 \\
\hline & Score & 1.00 & 3.00 & 2.00 & 2.00 & 3.00 & 1.00 \\
\hline \multirow{3}{*}{ Grain yield } & Weight & 3.00 & 3.00 & 3.00 & 5.00 & 5.00 & 5.00 \\
\hline & Score ${ }^{*}$ weight & 3.00 & 9.00 & 6.00 & 10.0 & 15.0 & 5.00 \\
\hline & Score & 0.00 & 0.00 & 0.00 & 2.00 & 2.00 & 3.00 \\
\hline \multirow[t]{3}{*}{ Tolerance to lodging } & Weight & 0.00 & 0.00 & 0.00 & 2.00 & 2.00 & 2.00 \\
\hline & Score* weight & 0.00 & 0.00 & 0.00 & 4.00 & 4.00 & 6.00 \\
\hline & Score & 3.00 & 2.00 & 1.00 & 0.00 & 0.00 & 0.00 \\
\hline \multirow{3}{*}{ Biomass yield } & Weight & 1.00 & 1.00 & 1.00 & 0.00 & 0.00 & 0.00 \\
\hline & Score* weight & 3.00 & 2.00 & 1.00 & 0.00 & 0.00 & 0.00 \\
\hline & Score & 2.00 & 1.00 & 3.00 & 2.00 & 2.00 & 3.00 \\
\hline \multirow[t]{2}{*}{ Tolerance to pest } & Weight & 2.00 & 2.00 & 2.00 & 3.00 & 3.00 & 3.00 \\
\hline & Score* weight & 4.00 & 2.00 & 6.00 & 6.00 & 6.00 & 9.00 \\
\hline$\sum$ (Score $*$ Weight $)$ & & 14.0 & 21.0 & 25.0 & 21.0 & 36.0 & 34.0 \\
\hline Rank & & 3.00 & 2.00 & 1.00 & 3.00 & 1.00 & 2.00 \\
\hline
\end{tabular}

Ranks: $1=$ best $2=$ fair $3=$ worst, the score multiplied by the weight to provide overall preference for each variety considering varied parameters.

Table 7. Pearson's correlation among farmers' preference rank and the actual measured traits rank.

\begin{tabular}{|c|c|c|c|c|c|c|c|c|c|c|}
\hline \multirow[b]{2}{*}{ Treatments } & & \multicolumn{3}{|c|}{ Grain yield rank } & \multicolumn{3}{|c|}{ Biomass yield rank } & \multicolumn{3}{|c|}{ Earliness rank } \\
\hline & & Actual & Farmers & $d^{2}$ & Actual & Farmers & $d^{2}$ & Actual & Farmers & $d^{2}$ \\
\hline \multirow{4}{*}{ Sekota } & IIP & 3 & 3 & $(3-3)^{2}$ & 2 & 1 & $(2-1)^{2}$ & 3 & 3 & $(3-3)^{2}$ \\
\hline & LIP & 1 & 2 & $(1-2)^{2}$ & 1 & 2 & $(1-2)^{2}$ & 2 & 2 & $(2-2)^{2}$ \\
\hline & LFP & 2 & 1 & $(2-1)^{2}$ & 3 & 3 & $(3-3)^{2}$ & 1 & 1 & $(1-1)^{2}$ \\
\hline & & \multicolumn{3}{|c|}{$r_{s}=0.5(50 \%)$} & \multicolumn{3}{|c|}{$r_{s}=0.5(50 \%)$} & \multicolumn{3}{|c|}{$r_{s}=1(100 \%)$} \\
\hline \multirow{4}{*}{ Lalibela } & IIP & 3 & 2 & $(3-2)^{2}$ & & & & 3 & 2 & $(3-2)^{2}$ \\
\hline & LIP & 1 & 1 & $(1-1)^{2}$ & & & & 2 & 2 & $(2-2)^{2}$ \\
\hline & LFP & 2 & 3 & $(2-3)^{2}$ & & & & 1 & 1 & $(1-1)^{2}$ \\
\hline & & \multicolumn{3}{|c|}{$r_{s}=0.5(50 \%)$} & & & & \multicolumn{3}{|c|}{$r_{s}=0.75(75 \%)$} \\
\hline
\end{tabular}

Where, $r_{\mathrm{s}}=$ correlation coefficient $d=$ difference in the ranks assigned to the same phenomenon and $n=$ number of phenomena ranked.

Conclusion

The participatory on-farm evaluation of different lentil production practices was generally intended to crack the paradox in the extension system in the marginal dry lands of Wag-lasta. Specifically, the experiment conducted to assess differences in lentil production practices under farmers' local context. Thus, the treatments were compared each other in representative districts. The result revealed that the LPP was better than other treatments in terms of mean grain yield and biomass yield, followed by LFP and IPP in descending order. The Tukey-HSD test also indicated that among treatments, LPP was best performing practice in grain and biomass yields while the LFP was best in days to maturity in all locations. The marginal rate of return similarly indicated that investing in IPP was not promising. Farmers and experts hence favoured to practice the package components for the local cultivar rather than using the improved variety. Therefore, based on the current finding, large scale dissemination of the local cultivar with its full production package is recommended pending to achieving new varieties that can out yield the existing local cultivar. Further studies thus should be in place to illuminate the genetic potential of lentil that can meet the identified farmers' preference traits.

\section{ACKNOWLEDGEMENT}

We are indebted for the involvement of farmers and extension workers who made tremendous effort throughout the experimental stages.

Declaration of interest

The authors have no any conflict of interest.

Open Access: This is an open access article published under the terms and conditions of Creative Commons AttributionNonCommercial 4.0 International License which permits noncommercial use, distribution, and reproduction in any medium, provided the original author(s) if the sources are credited. 


\section{REFERENCES}

Abraham, R. (2015). Lentil (Lens Culinaris Medikus) current status and future prospect of production in Ethiopia. Advances in Plants and \& Agriculture Research, 2(2): 00040.

Alaa, M. and Mahgoub, M.A. (2019). The impact of five environmental factors on species distribution and weed community structure in the coastal farmland and adjacent territories in the northwest delta region, Egypt. Heliyon, 5: 1441, https://doi.org/10.1016/j.heliyon.2019.e01441

Bacchi, M., Leone, M., Mercati, F., Preiti, G., Sunseri, F. and Monti, M. (2010). Agronomic evaluation and genetic characterization of different accessions in lentil (Lens culinaris Medik). Italian Journal of Agronomy, 4: 303-314, https:// doi.org/10.4081/ija.2010.303

Bejiga, G. and Anbessa, Y. (1998). Alemaya self-adjusting lentil variety to different environments in Ethiopia. NVRSRP Newsletter No, 1: 1-4.

CIMMYT. (1998). From Agronomic Data to Farmer Recommendations: An Economics Training Manual. Completely revised edition. Mexico. D.F.

Cokkizgin, A. and Munqez, J.Y. (2013). Lentil: Origin, cultivation techniques, utilization and advances in transformation. Agricultural Science, 1(1): 55-62, https:// doi.org/10.12735/as.v1i1p55

Central Statistical agency (CSA). (2016). Agricultural Sample Survey of 2015/2016, Report on Area and Production of Major Crops. Statistical Bulletin (Volume I), May 2015/16, Addis Ababa, Ethiopia.

Dhuppar, P., Biyan, S., Chintapalli, B. and Rao, S. (2012). Lentil crop production in the context of climate change: An Appraisal. Indian Research Journal of Extension Education, 2 (Special Issue): 33-35.

Dugassa, A., Legesse, H. and Geleta, N. (2015). Genetic variability, yield and yield associations of lentil (Lens culinaris Medic.) genotypes grown at Gitilo Najo, Western Ethiopia. Science and Technology Arts and Research Journal, 3: 10-18.

Eba, M. and Nano, A. (2018). Evaluation of lentil genotypes (Lens culinaris Medikus) for growth and yield performances across climate conditions of central highlands of Ethiopia. Turkish Journal of Agriculture - Food Science and Technology, 6(11): 1575-1581, https://doi.org/10.24925/turjaf.v6i11.1575-1581.2004

Erksine, W. (1983). Lentile genetic resource. In M.C. Saxena and S. Varma (Eds.), proceeding faba beans, kabuli chick peas, and lentil in the 1980 s, an international workshop, 16-20 May 1983, pp. 29-33. ICARDA, Aleppo, Syria. Retrieved from https://faostat.fao. org/faostat/servlet/

Food and Agricultural Organization of the United Nations (FAO). 2016. Food and Agricultural Organization of the United Nations Statistical Database, USA Retrieved from http://www.fao.org

Ferdous, Z., Datta, A., Anal, A.K., Anwar M. and Khan, M.R. (2016). Development of home garden model for year round production and consumption for improving resource-poor household food security in Bangladesh. NJAS - Wageningen Journal of Life Science, 78:103-110.

Frederick, M., Cho, S., Sarker, A., McPhee, K. and Coyne, C. (2006). Application of biotechnology in breeding lentil for resistance to biotic and abiotic stress. Euphytica, 147(1-2): 149-165.
Getahun, M. (2016). Review on Agronomic Practices for Improving Production and Productivity of Lentil in Ethiopia. Journal of Biology, Agriculture and Healthcare, 6(13): 102-106.

Institute of Biodiversity Conservation (IBC). (2007). Ethiopia: Second Country Report on the State of Plant genetic resources for food and agriculture to United Nations food and agricultural organization. Addis Ababa, Ethiopia.

Jarso, M., Korbu, L., Gebeyehu, S. and Alemayehu, F. (2009). Improved crop production practices for major pulses of Ethiopia; a training manual prepared for training of trainers Organized by Rural Capacity Building Project (RCBP). Ministry of Agriculture and Rural Development. Addis Ababa, Ethiopia.

Joseph, P., Gary, W. and Vincent, H. (2014). Lentils: Trends in Production, Trade, and Price. Briefing No. 61, Policy Center, Agricultural Marketing, Montana, USA.

Kumar, S., Barpete, S., Kumar, J., Gupta, P. and Sarker, A. (2013). Global Lentil Production: Constraints and Strategies. SATSA Mukhapatra - Annual Technical Issue, 17: 1-13.

Materne, M. and Siddique, K.H.M. (2009). Agro-ecology and lentil crop adaption. In: Erskine W., et al. (Eds.), The Lentil botany, Production and use. CAB International Ltd, Europe, pp. 47-63.

MOARD (Ministry of Agriculture and Rural Development). 2015. Crop Variety Register, 3(11): 68-73, Addis Ababa, Ethiopia.

Piergiovanni, A.R. (2000). The evaluation of lentil (Lens culinaris Medik.) cultivated in Italy and its effects on the survival of autochthonous populations. Genetic Resources and Crop Evolution, 47(3): 305-3014, https://doi.org/10.1023/A:1008789614680

Resenberg, I.H. (2005). Interdepartmental committee on nutrition for national defense surveys in Asia and Africa. Journal of Nutrition, 135(5): 1272-1275, https://doi.org/10.1093/jn/135.5.1272

Russell. (1997). Pair wise ranking made easy. In: PLA notes No 28, Methodological complimentary. International Institute of Environmental and Development (IIED), London, pp. 25-27.

Sarker, A. and Kumar, S. (2011). Lentils in production and food systems in West Asia and Africa. International Center for Agricultural Research in the Dry Areas (ICARDA), Aleppo, Syria. Grain Legumes, 57: 46-48.

SPSS (2007). SPSS User's Guide. Released V-16 editions. SPSS Institute Inc., Cary, North Carolina.

Woreda Office of Agricultural Development (WOA) (2015). Basic geographical information of Abergele Woreda: A working manual. Prepared by regional advisory experts. Bahir Dar, Ethiopia.

Yadav, D.B., Kamboj, B.K. And Garg, R.B. (2004). Increasing the productivity and profitability of sunflower through front line demonstrations in irrigated agro -ecosystem of eastern Haryana. Haryana Journal of Agronomy, 20(1-2): 33-35.

Yasin, G. (2015). Current research in agricultural sciences performance evaluation and adaptation of lentil varieties in Lima, Gumur, and Damot Gale Districts of Southern. Journal Current Research in Agricultural Sciences, 2(2): 53-59, https://doi.org/10.18488/ journal.68/2015.2.2/68.2.53.59

Yirga, K. and Zinabu, N. (2018). Participatory evaluation of lentil varieties in Wag-lasta, Eastern Amhara. Cogent Food and Agriculture, 4: 1561171, https://doi.org/10.1080/23311932.2018.1561171 